\title{
Effect of Mushroom on the Lipid Profile, Lipid Peroxidation and Liver Functions of Aging Swiss Albino Rats
}

\author{
Sanjay Mishra, ${ }^{1, *}$ and R.B. Singh ${ }^{2}$ \\ ${ }^{I}$ Department of Biotechnology, College of Engineering \& Technology, IFTM Campus, Lodhipur Rajput, Delhi Road, \\ Moradabad 244 001, U.P., India \\ ${ }^{2}$ Halberg Hospital and Research Institute, Civil Lines, Moradabad 244 001, U.P., India
}

\begin{abstract}
Introduction: Mushrooms are a manifestation of a common saying, 'Medicines and foods have a common origin', in constituting both a nutritionally functional food and a source of physiologically beneficial medicine. The present studies were undertaken to investigate the effects of dried mushroom and mushroom extract on the lipid profile, lipid peroxidation and liver function of aging Swiss albino rats as compared with L-carnitine.

Materials \& Methods: Male Swiss albino rats of Wister strain of the age of 45 days weighing approximately $320 \pm 8 \mathrm{~g}$ were used. The animals were fed a basal diet for one week as an adaptation period. The basal diet was formulated including essential ingredients. Water was available ad libitum. The animals were divided to five groups. The first group (control) fed the basal diet. The second and the third groups fed L-carnitine ( 400 and $800 \mathrm{mg} / \mathrm{kg}$ body weight/day, respectively) in $0.9 \%$ saline at physiological $\mathrm{pH}$. The fifth and sixth groups were fed $15 \%$ dried mushroom and $450 \mathrm{mg} / \mathrm{kg}$ body weight/day mushroom extract, respectively. Blood samples were taken at the beginning of the experiment and at the end of experiment (4 weeks) from orbital plexus versus by means of fine capillary glass tubes, sera were separated, and lipid profile, lipid peroxidation stage and liver function profile were determined according to the well established methodology after slight modifications.

Results \& Conclusion: Mushroom and their extracts were comparable to L-carnitine in controlling lipid peroxidation. Dried mushroom and their extract can improve the antioxidant status during aging and minimize the occurrence of ageassociated disorders as a consequence of the involvement of free radicals. The results obtained from the present studies provide new insights into work to be carried out on histological examination of liver tissues of rats fed basal diet, and may project the congestion of the central vein and infiltration with chronic inflammatory cells. These examinations may also show slight hydropic degeneration of hepatocytes and vacuolations of some hepatocytes and small focal hepatic necrosis.
\end{abstract}

Keywords: L-carnitine, Lipid peroxidation, Lipid profile, Liver function, Mushroom, Mushroom extract, Swiss Albino rat,

\section{INTRODUCTION}

In fact, aging is associated with biochemical and structural alterations which are thought to result in motor and cognitive impairments and in increased susceptibility to neurodegenerative diseases [1-4]. The free radical theory of aging proposed that aging is due to the accumulation of unrepaired damage from free radical attack on cellular components. Modern approaches propose that aging is caused by a shift in the balance between the pro-oxidative and antioxidative processes in the direction of the pro-oxidative state $[1,2,5-7]$. L-carnitine, a nutrient normally synthesized from methionine and lysine in the liver and kidney. L- carnitine transports long-chain fatty acids (LCFA) across the mitochondrial membrane where they undergo beta-oxidation to produce energy. Carnitine deficiency decreases LCFA availability for oxidation, thereby resulting in LCFA accumulation

\footnotetext{
*Address correspondence to this author at the Department of Biotechnology \& Research College of Engineering \& Technology IFTM Campus, Lodhipur Rajput, Delhi Road, Moradabad 244001, U.P., India;

Tel: +91-591-2360817; Fax: +91-591-2360818;

Email: sanjaymishra66@gmail.com and sanjay_mishra23@rediffmail.com
}

in the cytosol, and decreased ketone and energy production. Other L-carnitine functions include the maintenance of adequate free coenzyme-A required for various metabolic pathways, the protection of cells against toxic accumulation of acyl-coenzyme-A compounds by shuttling acyl groups out of the mitochondria, and the storage and transport of energy [8]. Also, L-carnitine supports the immune system and enhances the antioxidant system [9].

Mushrooms are a manifestation of a common saying, 'Medicines and foods have a common origin', in constituting both a nutritionally functional food and a source of physiologically beneficial medicine. Many centuries ago, medicinal properties of mushrooms have been recognized in China, Korea and Japan. Although from ancient times, mushrooms have been treated as a special kind of nutraceutical, they have received a remarkable interest in recent decades. Major medicinal properties attributed to mushrooms include anticancer activity, antibiotic activity, antiviral activity, immune response-stimulating effects, anti-hypersensitive and blood lipid lowering effects [10-12]. Mushroom is known to have high amounts of proteins, carbohydrates and fibers and low fat contents [13]. Furthermore, mushroom had significant 
levels of vitamins, namely thiamine, riboflavin, ascorbic acid and vitamin $\mathrm{D}_{2}$, as well as minerals [14]. Mushroom species had been shown to possess antioxidant capacity in in-vitro systems [15-18]. The mushroom Pleurotus species ( $P$. ostreatus, P. sajor-caju, P. florida) were reported to have hypocholesterolemic activity in experimental rats [18-20]. It has been reported that the L- carnitine concentration in mushroom ranged from 130 to $533 \mathrm{mg} / \mathrm{kg}$ dried mushroom [21]. The free L- carnitine concentration in mushroom ranged from 75 to $385 \mathrm{mg} / \mathrm{kg}$ dried mushroom, which represented $70 \pm 10 \%$ of total carnitine content. Therefore, the present studies were undertaken to investigate the effects of dried mushroom and mushroom extract on the lipid profile, lipid peroxidation and liver function of aging Swiss albino rats as compared with L-carnitine.

\section{MATERIALS AND METHODS}

L-carnitine was purchased from Sigma Chemical Co. (St. Louis, MO, USA). Total cholesterol, HDL-cholesterol, LDLcholesterol, total lipids, alkaline phosphatase (ALP), aspartate amino transferase (AST), alanine amino transferase (ALT), glutathione peroxidase (GSH) and malonaldehyde (MDA) kits were obtained from Randox Laboratories Ltd, England.

Pleurotus ostreatus was cultivated adopting the "layer spawning" method. Whole mushrooms were dried in the shade and then finely powdered. Dried mushrooms were ground to pass through a 60 mesh sieve. Seventy five grams of dried mushrooms were extracted with $225 \mathrm{ml}$ of $95 \%$ ethanol using a Soxhlet apparatus. The residue was filtered and concentrated to a dry mass by vacuum distillation and used as mushroom extract.

Male Swiss albino rats of Wister strain of the age of 45 days weighing approximately $320 \pm 8 \mathrm{~g}$ were used. A total of forty Swiss albinos male rats were raised in the central animal house facility at CET-IFTM, Moradabad, India. The animals were fed a basal diet for one week as an adaptation period. The basal diet was formulated according to AIN [22] and consisted of casein (12\%), corn oil $(10 \%)$, cellulose $(5 \%)$, salt mixture $(4 \%)$, vitamin mixture $(1 \%)$ and starch (68\%). Water was available ad libitum. The animals were divided to five groups. The first group (control) fed the basal diet. The second and the third groups fed L-carnitine (400 and $800 \mathrm{mg} / \mathrm{kg}$ body weight/day, respectively) in $0.9 \%$ saline at physiological $\mathrm{pH}$. The fifth and sixth groups were fed $15 \%$ dried mushroom and $450 \mathrm{mg} / \mathrm{kg}$ body weight/day mushroom extract, respectively. This study was duly approved by Institutional Animal Ethical Committee.

Blood samples were taken at the beginning of the experiment and at the end of experiment (4 weeks) from orbital plexus versus by means of fine capillary glass tubes according to the method described by Schermer [23]. The blood samples were placed in dry and clean centrifuge tubes and allowed to clot for $1-2 \mathrm{~h}$ at room temperature. Serum was removed using a Pasteur pipette and centrifuged for $20 \mathrm{~min}$ at $1100 \mathrm{x} \mathrm{g}$. The clean supernatant serum was kept frozen until analysis. Body weights of animals were recorded at the start of the experiment and at the end of experiment. As far as sample size determination was concerned, systematic sampling statistical method was employed in the present study [24].

The serum triacylglycerides, low density lipoprotein (LDL), high-density lipoprotein (HDL), total cholesterol and total lipid were determined according to the methods described herein [25-29]. Alanine amino transferase (ALT), aspartate amino transferase (AST) and alkaline phosphatase (ALP) enzymes were measured according to the methods described by research groups [30-32]. Glutathione peroxidase enzyme (GSH) and malonaldehyde (MDA) were determined according to the methods described by $\mathrm{Hu}$, and Jentzsch et al. [33, 34], respectively.

The data obtained were analyzed using the analysis of variance (ANOVA) to determine differences $[35,36]$ and Duncan's Multiple Range Test (DMRT) to separate the means [37].

\section{RESULTS AND DISCUSSION}

The effect of $15 \%$ dried mushroom, $450 \mathrm{mg}$ mushroom extract and L-carnitine on total lipid, triglyceride and total cholesterol is shown in Table $\mathbf{1}$. Total lipid content significantly $(\mathrm{P} \leq 0.05)$ reduced in albino rats supplemented with mushroom and L-carnitine. The reduction in the total lipids ranged from 7.06 to $14.39 \%$. There was no significant $(\mathrm{P}>$ $0.05)$ difference in total lipid between rats supplemented with $400 \mathrm{mg}$ L-carnitine and those supplemented with $15 \%$ dried mushroom. Albino rats supplemented with $800 \mathrm{mg} \mathrm{L}$ carnitine had a higher $(\mathrm{P} \leq 0.05)$ total lipid content compared to those supplemented with $450 \mathrm{mg}$ mushroom extract. Diet

Table 1. Effect of Dried Mushroom, Mushroom Extract and L-Carnitine on Lipid Profile of Aging Rats

\begin{tabular}{|c|c|c|c|c|c|c|c|c|c|}
\hline \multirow{2}{*}{ Groups } & \multicolumn{3}{|c|}{ Total Lipids (mg/dl) } & \multicolumn{3}{|c|}{ Triglyceride (mg/dl) } & \multicolumn{3}{|c|}{ Total Cholesterol (mg/dl) } \\
\hline & Before & After & \% Changes & Before & After & \% Changes & Before & After & \% Changes \\
\hline Aged rats control & $484.54 \pm 8.31$ & $479.03 \pm 4.79$ & -1.14 & $194.5 \pm 8.16$ & $163.3 \pm 9.13$ & -16.07 & $166.2 \pm 4.68$ & $160.7 \pm 4.31$ & -3.29 \\
\hline Aged rats with $400 \mathrm{mg} \mathrm{LC}$ & $485.21 \pm 4.51$ & $445.22 \pm 6.96$ & -8.24 & $213.5 \pm 8.63$ & $146.7 \pm 3.64$ & -31.28 & $165.49 \pm 3.75$ & $139.15^{\mathrm{b}} \pm 4.55$ & -15.92 \\
\hline Aged rats with $800 \mathrm{mg} \mathrm{LC}$ & $480.55 \pm 5.59$ & $435.70 \pm 6.35$ & -9.33 & $199.6 \pm 8.61$ & $121.5 \pm 4.21$ & -39.13 & $165.15 \pm 3.51$ & $118.16 \pm 3.61$ & -28.45 \\
\hline Aged rats with $15 \%$ DM & $476.60 \pm 8.23$ & $442.95 \pm 6.4$ & -7.06 & $215.1 \pm 5.11$ & $139.5 \pm 3.41$ & -35.15 & $163.61 \pm 4.01$ & $130.45 \pm 4.72$ & -20.27 \\
\hline Aged rats with $400 \mathrm{mg} \mathrm{ME}$ & $485.02 \pm 6.53$ & $415.22 \pm 2.18$ & -14.39 & $215.9 \pm 4.31$ & $121.5 \pm 1.39$ & -43.72 & $160.52 \pm 4.53$ & $120.00 \pm 3.65$ & -25.24 \\
\hline
\end{tabular}

Values are expressed in blood serum samples as means \pm SD of 8 rats from each group with triplicates in each set of experiment. 
supplemented with mushroom and L-carnitine resulted in a significant $(\mathrm{P} \leq 0.05)$ decrease in triglyceride and total cholesterol level. Triglyceride was observed to reduce by $31.28-43.72 \%$. However, total cholesterol reduced by $15.92-$ $28.45 \%$. Supplementation with $450 \mathrm{mg}$ mushroom extract and $800 \mathrm{mg}$ L-carnitine were more $(\mathrm{P} \leq 0.05)$ effective in reducing triglyceride and total cholesterol than those supplemented with $15 \%$ dried mushroom and $400 \mathrm{mg}$ Lcarnitine. On the other hand, supplementation with $450 \mathrm{mg}$ mushroom extract and $800 \mathrm{mg}$ L-carnitine were similar $(\mathrm{P}>$ $0.05)$ in reducing triglyceride and total cholesterol levels. Supplementation with $15 \%$ dried mushroom and $400 \mathrm{mg}$ Lcarnitine were also similar $(\mathrm{P}>0.05)$ in reducing triglyceride and total cholesterol. It has been observed that rats fed a semisynthetic diet containing $0.3 \%$ cholesterol and supplemented with $5 \%$ dried whole oyster mushroom had reduced serum and liver cholesterol levels by 34 and 58\%, respectively [38]. Panchamoorthy and Carani [39] reported that treated rats with L-carnitine caused a significant reduced in TG as compared to untreated rats. L-carnitine is known to promote the transport of cytosolic long-chain fatty acids into the mitochondrial matrix for $\beta$-oxidation, thereby providing mitochondrial energy [40, 41]. L-carnitine may lower plasma TG by increasing the utilization and/or oxidation of fatty acids for energy or possibly by altering very low-density lipoprotein synthesis [42].

The data expressed in Table 2 indicate that the high density lipoprotein in rats was not affected $(\mathrm{P}>0.05)$ as a consequence of the supplementation with $15 \%$ dried mushroom and $400 \mathrm{mg}$ L-carnitine. However, rats supplemented with $450 \mathrm{mg}$ mushroom extract and $800 \mathrm{mg}$ L-carnitine had a higher $(\mathrm{P} \leq 0.05)$ high density lipoprotein compred to those of the control sets. High density lipoprotein was monitored to enhance in these albino rats by $24.11-30.44 \%$. Low density lipoprotein $(\mathrm{P} \leq 0.05)$ reduced in albino rats supplemented with mushroom and L-carnitine by $30.36-55.76 \%$. Supplementation of rats with $450 \mathrm{mg}$ mushroom extract and $800 \mathrm{mg}$ L-carnitine were more $(\mathrm{P} \leq 0.05)$ effective in lowering low density lipoprotein than those supplemented with $15 \%$ dried mushroom and $400 \mathrm{mg}$ L-carnitine. On the other hand, supplementation of rats with $450 \mathrm{mg}$ mushroom extract and $800 \mathrm{mg}$ L-carnitine were similar $(\mathrm{P}>0.05)$ in decreasing low density lipoprotein. Supplementation of rats with $15 \%$ dried mushroom and $400 \mathrm{mg}$ L-carnitine were also similar $(\mathrm{P}>0.05)$ in lowering low density lipoprotein. Very low density lipoprotein in rats was $(\mathrm{P} \leq 0.05)$ reduced by the supplementation with mushroom and L-carnitine. Very low density lipoprotein was reduced in these rats by 32.33-42$21 \%$. Supplementation of rats with $450 \mathrm{mg}$ mushroom extract and $800 \mathrm{mg}$ L-carnitine were more $(\mathrm{P} \leq 0.05)$ effective in reducing very low density lipoprotein than those supplemented with $15 \%$ dried mushroom and $400 \mathrm{mg}$ L-carnitine. Diet supplemented with $450 \mathrm{mg}$ mushroom extract and 800 mg L-carnitine did not significantly $(\mathrm{P}>0.05)$ differ in their effect on very low density lipoprotein. Besides, no significant $(\mathrm{P}>0.05)$ difference was observed in very low density lipoprotein between albino rats supplemented with $15 \%$ dried mushroom and those supplemented with $400 \mathrm{mg} \mathrm{L}$ carnitine. These results are in agreement with those reported earlier [42, 43] highlighting that L-carnitine well stabilizes the level of lipids peroxidation, decreases concentration of total lipids, triglycerides, total cholesterol, phospholipids, and lipoproteins of low and very low density, in the Swiss albino rats blood sera.

Table 3 indicates that the aspartate amino transferase (AST) enzyme in rats was assessed to significantly $(\mathrm{P} \leq$ $0.05)$ reduce by the supplementation of diet with mushroom and L-carnitine. Mushroom reduced AST enzyme by 38.64$41.46 \%$. However, L-carnitine reduced it by $24.58-42.80 \%$. Swiss albino rats supplemented with $400 \mathrm{mg}$ L-carnitine showed a higher $(\mathrm{P} \leq 0.05)$ AST enzyme compared to those supplemented with mushroom and $800 \mathrm{mg}$ L-carnitine. Diet supplemented with $450 \mathrm{mg}$ mushroom extract and $800 \mathrm{mg} \mathrm{L}-$ carnitine were not significantly $(P>0.05)$ differed in their impact on AST enzyme. Further, diet supplemented with mushroom and L-carnitine had a lower $(\mathrm{P} \leq 0.05)$ alanine amino transferase (ALT) enzyme compared to that of the control sets. Mushroom and L-carnitine reduced ALT enzyme by $36.59-45.61 \%$ and $22.40-36.99 \%$, respectively. Diet supplemented with $15 \%$ dried mushroom, $450 \mathrm{mg}$ mushroom extract and $800 \mathrm{mg}$ L-carnitine appeared to be more effective $(\mathrm{P}>0.05)$ in decreasing ALT enzyme compared to those supplemented with $400 \mathrm{mg}$ L-carnitine. No significant $(\mathrm{P}>$ $0.05)$ difference was found in ALT enzyme among rats supplemented with $15 \%$ dried mushroom, $450 \mathrm{mg}$ mushroom extract and those supplemented with $800 \mathrm{mg}$ L-carnitine. The alkaline phosphatase (ALP) enzyme in rats was observed to significantly $(\mathrm{P} \leq 0.05)$ reduce by the supplementation with mushroom and L-carnitine. Mushroom reduced ALP enzyme by 22.19-32.71\%. However, L-carnitine re-

Table 2. Effect of Dried Mushroom, Mushroom Extract and L-Carnitine on Lipoprotein of Aging Rats

\begin{tabular}{|c|c|c|c|c|c|c|c|c|c|}
\hline \multirow{2}{*}{ Groups } & \multicolumn{3}{|c|}{ High Density Lipoproteins (mg/dl) } & \multicolumn{3}{|c|}{ Low Density Lipoproteins (mg/dl) } & \multicolumn{3}{|c|}{ Very Low Density Lipoproteins (mg/dl) } \\
\hline & Before & After & $\%$ Changes & Before & After & \% Changes & Before & After & $\%$ Changes \\
\hline Aged rats control & $49.18 \pm 2.56$ & $53.31 \pm 4.07$ & +8.40 & $76.58 \pm 4.83$ & $72.37 \pm 3.03$ & -5.49 & $39.52 \pm 2.54$ & $33.06 \pm 2.63$ & -16.34 \\
\hline Aged rats with $400 \mathrm{mg} \mathrm{LC}$ & $48.36 \pm 3.14$ & $55.46 \pm 5.44$ & +14.68 & $71.83 \pm 2.51$ & $50.02 \pm 0.36$ & -30.36 & $41.35 \pm 1.83$ & $27.97 \pm 0.64$ & -32.33 \\
\hline Aged rats with $800 \mathrm{mg} \mathrm{LC}$ & $51.01 \pm 3.52$ & $63.31 \pm 3.01$ & +24.11 & $76.04 \pm 4.69$ & $33.64 \pm 0.11$ & -55.76 & $39.17 \pm 2.31$ & $24.31 \pm 1.05$ & -37.93 \\
\hline Aged rats with $15 \%$ DM & $47.65 \pm 2.76$ & $52.73 \pm 3.61$ & +10.66 & $73.89 \pm 4.72$ & $51.65 \pm 3.10$ & -30.09 & $41.06 \pm 1.49$ & $27.09 \pm 0.88$ & -34.02 \\
\hline Aged rats with $400 \mathrm{mg} \mathrm{ME}$ & $49.25 \pm 3.62$ & $64.24 \pm 2.61$ & +30.44 & $71.45 \pm 5.88$ & $33.40 \pm 1.18$ & -53.25 & $41.77 \pm 1.21$ & $24.14 \pm 1.41$ & -42.21 \\
\hline
\end{tabular}

Values are expressed in blood serum samples as means \pm SD of 8 rats from each group with triplicates in each set of experiment. 
duced it by $22.14-49.26 \%$. The Diet supplemented with 400 mg L-carnitine had a higher $(\mathrm{P} \leq 0.05)$ ALP enzyme compared to those supplemented with $800 \mathrm{mg}$ L-carnitine. Diet supplemented with $15 \%$ dried mushroom had a higher $(\mathrm{P} \leq$ 0.05) ALP enzyme compared to those supplemented with $450 \mathrm{mg}$ mushroom extract. The diet supplemented with $15 \%$ dried mushroom and $400 \mathrm{mg}$ L-carnitine were not significantly $(\mathrm{P}>0.05)$ differed in their impact on ALP enzyme. Lcarnitine and mushroom restores the changes of ALT, AST and ALP activities due to their antioxidant effects and their ability to act as a radical scavenger, thereby protecting membrane permeability. Augustyniak and Skrzydlewska (2009) [44] found that ALT and AST after ethanol intoxication their activity increased by about $80 \%$. L-carnitine partly prevented these changes. It was manifested by a statistically significant decrease in the activity of ALT and AST, by about $20 \%$ in comparison with the ethanol group.

The Data shown in Table 4 reflect that the MDA ( $\mathrm{P} \leq$ $0.05)$ got reduced by $11.92-33.79 \%$ in albino rats supplemented with diet containing mushroom and L-carnitine. Supplementation with $450 \mathrm{mg}$ mushroom extract and 800 mg L-carnitine were more $(\mathrm{P} \leq 0.05)$ effective in decreasing MDA compared to those supplemented with $15 \%$ dried mushroom and $400 \mathrm{mg} \mathrm{L}$-carnitine. On the other hand, supplementation with $450 \mathrm{mg}$ mushroom extract and $800 \mathrm{mg} \mathrm{L}-$ carnitine were similar $(\mathrm{P}>0.05)$ in reducing MDA. Supplementation of diets with $450 \mathrm{mg}$ mushroom extract and 400 $\mathrm{mg}$ L-carnitine were also similar $(\mathrm{P}>0.05)$ in reducing
MDA. Rats supplemented with the diet containing 15\% dried mushroom had higher $(\mathrm{P} \leq 0.05)$ MDA compared to those supplemented with $400 \mathrm{mg}$ L-carnitine. It has earlier been reported that administration of L-carnitine to rats intoxicated with ethanol significantly protects lipids and proteins against oxidative modifications in the serum and liver. The level of MDA was decreased by about $30 \%$, in the blood serum in comparison to the ethanol group [44].

Glutathione peroxidase (GSHPx) is known to perform a key role in co-coordinating the innate antioxidant defense mechanisms. It is involved in the maintenance of the normal structure and function of cells, probably by its redox and detoxification reactions $[1,2,45]$. The GSHPx in rats was monitored to be significantly $(\mathrm{P} \leq 0.05)$ enhanced by the supplementation with mushroom and L-carnitine. Mushroom increased GSHPx by 58.43-85.50\%. However, L-carnitine increased it by $60.15-129.69 \%$. Rats supplemented with 450 $\mathrm{mg}$ L-carnitine and 15\% dried mushroom had a lower ( $\mathrm{P} \leq$ 0.05) GSHPx compared to those supplemented with $800 \mathrm{mg}$ L-carnitine and $450 \mathrm{mg}$ mushroom extract. Supplementation with $15 \%$ dried mushroom and $400 \mathrm{mg} \mathrm{L}$-carnitine were not significantly ( $P>0.05$ ) differed in their effect on GSHPx. Supplementation of rats with $800 \mathrm{mg}$ L-carnitine was more $(\mathrm{P} \leq 0.05)$ effective in increasing GSHPx compared to those supplemented with $400 \mathrm{mg}$ L-carnitine, $15 \%$ dried mushroom and $450 \mathrm{mg}$ mushroom extract. According to Augustyniak and Skrzydlewska [44] L-carnitine has been reported to cause a significant increase in the liver and blood

Table 3. Effect of Dried Mushroom, Mushroom Extract and L-Carnitine on Liver Functions of Aging Rats

\begin{tabular}{|c|c|c|c|c|c|c|c|c|c|}
\hline \multirow{2}{*}{ Groups } & \multicolumn{3}{|c|}{ Aspartate Aminotransferase (AST) (U/ml) } & \multicolumn{3}{|c|}{ Alanine Aminotransferase (ALT) (U/ml) } & \multicolumn{3}{|c|}{ Alkaline Phosphatase (ALP) (U/ml) } \\
\hline & Before & After & $\%$ Changes & Before & After & $\%$ Changes & Before & After & $\%$ Changes \\
\hline Aged rats control & $82.15 \pm 2.11$ & $76.35 \pm 2.40$ & -7.06 & $42.60 \pm 1.73$ & $40.15 \pm 3.40$ & -5.81 & $62.11 \pm 3.14$ & $62.52 \pm 2.41$ & +0.66 \\
\hline Aged rats with $400 \mathrm{mg} \mathrm{LC}$ & $80.98 \pm 3.52$ & $61.87 \pm 3.52$ & -24.58 & $44.12 \pm 1.92$ & $34.26 \pm 3.30$ & -22.40 & $61.64 \pm 3.42$ & $48.61 \pm 4.91$ & -21.14 \\
\hline Aged rats with $800 \mathrm{mg} \mathrm{LC}$ & $81.26 \pm 3.41$ & $46.48 \pm 1.41$ & -42.80 & $42.15 \pm 1.79$ & $26.56 \pm 1.52$ & -36.99 & $62.91 \pm 3.52$ & $31.92 \pm 2.11$ & -49.26 \\
\hline Aged rats with $15 \%$ DM & $82.95 \pm 2.35$ & $50.89 \pm 2.13$ & -38.64 & $42.50 \pm 2.31$ & $26.95 \pm 1.31$ & -36.59 & $64.45 \pm 2.14$ & $50.15 \pm 2.84$ & -22.19 \\
\hline Aged rats with $400 \mathrm{mg} \mathrm{ME}$ & $83.79 \pm 2.42$ & $49.05 \pm 2.65$ & -41.46 & $42.56 \pm 1.98$ & $23.15 \pm 2.01$ & -45.61 & $61.40 \pm 2.64$ & $41.32 \pm 1.21$ & -32.71 \\
\hline
\end{tabular}

Values are expressed in blood serum samples as means \pm SD of 8 rats from each group with triplicates in each set of experiment.

Table 4. Effect of Dried Mushroom, Mushroom Extract and L-Carnitine on MDA and GSHPx of Aging Rats

\begin{tabular}{|l|c|c|c|c|c|c|}
\hline \multirow{2}{*}{ Groups } & \multicolumn{3}{|c|}{ MDA(n mol/ml) } & \multicolumn{2}{c|}{ GSHPx (U/ml) } \\
\cline { 2 - 7 } & Before & After & \% Changes & Before & After & \% Changes \\
\hline \hline Aged rats control & $24.81 \pm 2.11$ & $25.39 \pm 1.46$ & +1.82 & $11.1 \pm 3.50$ & $11.54 \pm 2.71$ & +1.65 \\
\hline Aged rats with 400 mg LC & $26.39 \pm 2.14$ & $19.04 \pm 0.54$ & -27.9 & $13.11 \pm 3.38$ & $21.96 \pm 2.61$ & +60.15 \\
\hline Aged rats with 800 mg LC & $25.92 \pm 1.61$ & $17.16 \pm 1.31$ & -33.79 & $12.04 \pm 2.91$ & $31.59 \pm 2.91$ & +129.69 \\
\hline Aged rats with 15\% DM & $24.58 \pm 2.41$ & $21.65 \pm 1.51$ & -11.92 & $10.98 \pm 4.61$ & $19.41 \pm 1.61$ & +58.43 \\
\hline Aged rats with 400 mg ME & $24.45 \pm 1.46$ & $18.15 \pm 0.90$ & -25.7 & $14.01 \pm 4.01$ & $25.98 \pm 2.51$ & +85.50 \\
\hline
\end{tabular}

Values are expressed in blood serum samples as means \pm SD of 4 rats from each group with triplicates in each set of experiment. 
Table 5. Effect of Dried Mushroom, Mushroom Extract and L-Carnitine on Food Intake and Body Weight of Aging Rats

\begin{tabular}{|l|c|c|c|}
\hline \multirow{2}{*}{ Groups } & \multirow{2}{*}{ Food Intake (g/day) } & \multicolumn{2}{|c|}{ Body Weight (g) } \\
\cline { 3 - 4 } & & Initial & Final \\
\hline \hline Aged rats control (G1) & $9.4 \pm 1.15$ & $316.6 \pm 9.85$ & $328.5 \pm 8.51$ \\
\hline Aged rats with 400 mg LC (G2) & $17.6 \pm 2.14$ & $318.2 \pm 8.38$ & $276.6 \pm 8.15$ \\
\hline Aged rats with 800 mg LC (G3) & $18.3 \pm 1.99$ & $311.6 \pm 9.16$ & $269.6 \pm 7.63$ \\
\hline Aged rats with 15\% DM (G4) & $17.4 \pm 1.86$ & $313.4 \pm 9.47$ & $318.4 \pm 8.05$ \\
\hline Aged rats with 400 mg ME (G5) & $17.7 \pm 1.91$ & $315.8 \pm 8.54$ & $319.57 \pm 8.17$ \\
\hline
\end{tabular}

Values are means \pm SD of 8 rats from each group with triplicates in each set of experiment.

serum GSH level by more than $20 \%$. An increase in the levels of GSHPx in aged rats treated with mushroom extract as a source of antioxidant has also been recently reported $[45,46]$.

Table 5 highlights the effect of dried mushroom, mushroom extract and L-carnitine on food intake and body weight of Swiss albino rats. Either L-carnitine or mushroom significantly $(\mathrm{P} \leq 0.05)$ increased food intake and reduced body weight in rats. There was no significant $(P>0.05)$ variation in food intake between rats supplemented with L-carnitine and mushroom. Supplementation of rats with L-carnitine was more $(\mathrm{P} \leq 0.05)$ effective in reducing body weight than those supplemented with mushroom. Supplemented rats with 400 $\mathrm{mg}$ L-carnitine and $800 \mathrm{mg}$ L-carnitine were not significantly $(\mathrm{P}>0.05)$ distinct in their effect on body weight. Similar effect was monitored in rats supplemented with $15 \%$ dried mushroom and $450 \mathrm{mg}$ mushroom extract. The rationale for L- carnitine supplementation as a weight-loss agent is based on the assumption that regular oral ingestion of the substance increases its intracellular concentration. This would trigger increased fat oxidation and gradual reduction of the body's fat reserves [47, 48].

\section{CONCLUDING REMARKS}

Conclusively, mushroom and their extracts were comparable to L-carnitine in controlling lipid peroxidation. Dried mushroom and their extract can improve the antioxidant status during aging and minimize the occurrence of ageassociated disorders as a consequence of the involvement of free radicals. The results obtained so far from the present studies provide new insights into work to be carried out on histological examination of liver tissues of rats fed basal diet, and may project the congestion of the central vein and infiltration with chronic inflammatory cells. These examinations may also show slight hydropic degeneration of hepatocytes and vacuolations of some hepatocytes and small focal hepatic necrosis.

\section{ACKNOWLEDGEMENTS}

The present work was supported by a joint venture of Halberg Hospital and Research Institute, Civil Lines, Moradabad 244 001, U.P., India and College of Engineering Technology, IFTM, Moradabad, U.P., India. The authors are grateful to Dr. R.M. Dubey (Managing Director) and Prof. A. Srivastav (Director), CET, IFTM Campus, Moradabad,
U.P., India for providing necessary facilities and encouragement. Besides, critical reading of the manuscript by S.P. Dwivedi is duly acknowledged.

\section{REFERENCES}

[1] Sharma V, Kalim S, Srivastava MK, Nanda S, Mishra S. Oxidative stress and coxsakievirus infections act as mediators of beta cell damage: a review. Sci Res Essay 2009; 4 (2): 42-58.

[2] Nanda S, Mishra S, Varshney VP, Singh RB. A biotechnological approach to apoptosis of somatic and germ cells in living organisms. Open Nutra J 2010; 3: 81-93.

[3] Freo U, Pizzolato G, Dam M, Ori, C, Battistin L. A short review of cognitive and functional neuroimaging studies of cholinergic drugs: implications for therapeutic potentials. J Neural Transm 2002; 109: 857-70.

[4] Terry J, Buccafusco JJ. The cholinergic hypothesis of age and Azheimer's disease-related cognitive deficits: recent challenges and their implications for novel drug development. J Pharmacol Exp Ther 2003; 306: 821-27.

[5] Harman D. Free radical theory of aging. Mutat Res 1992; 275: 257-66.

[6] Beckman B, Ames BN. The free radical theory of aging matures. Physiol Rev 1998; 78: 547-81.

[7] Cadenas E, Davies KJ. Mitochondrial free radical generation, oxidative stress and aging. Free Radic Biol Med 2000; 29: 222-30.

[8] Catherine MC, Michael CS, Michael LC, et al. Carnitine supplementation in premature neonates: Effect on plasma and red blood cell total carnitine concentrations, nutrition parameters and morbidity. Clin Nutr 2006; 25: 886-96.

[9] Bremer J. The role of carnitine in cell metabolism. In: De Simone C, Famularo G, Eds. Molecular Biology Intelligence Unit Carnitine Today (Landes Bioscience Austin, TX, USA, International Copyright). Heidelberg, Germany, Sringer Verlag 1997; pp. 4-37.

[10] Wasser SP, Weis AL. Medicinal properties of substances occurring in higher Basidiomycetes mushrooms: Current perspectives. Int J Med Mushr 1999; 1(1): 31-62.

[11] Kaul TN. Biology and Conservation of mushrooms. New Delhi: Oxford \& IBH Publishing Co. Pvt. Ltd 2001: pp. 117- 45.

[12] Yang JH, Lin HC, Mau JL. Antioxidant properties of several commercial mushrooms. Food Chem 2002; 77: 229-35.

[13] Bárbara R, Rosário L, Paula B, et al. Comparative study of phytochemicals and antioxidant potential of wild edible mushroom caps and stipes. Food Chem 2008; 110: 47-56.

[14] Mattila P, Suonpaa K, Piironen V. Functional properties of edible mushrooms. Nutrition 2000; 16: 694-96.

[15] Ribeiro B, Rangel J, Valentáo P, et al. Contents of carboxylic acids and two phenolics and antioxidant activity of dried portuguese wild edible mushrooms. J Agric Food Chem 2006; 54: 8530-7.

[16] Diaz M, Lopez F, Hernandez F, Urbina JA. L-carnitine effects on chemical composition of plasma lipoproteins of rabbits fed with normal and high cholesterol diets. Lipids 2000; 35: 627-32.

[17] Ribeiro B, Valentáo P, Baptista P, et al. Phenolic compounds, organic acids profiles and antioxidative properties of beefsteak fungus (Fistulina hepatica). Food Chem Toxicol 2007; 45(10): 1805-13. 
[18] Khan MA, Tania M, Zhang D-Z. Chen H-C. Cordyceps mushroom: a potent anticancer nutraceutical. Open Nutra J 2010; 3: 179-83.

[19] Hossain S, Hashimoto M, Choudhury EK, et al. Dietary mushroom (Pleurotus ostreatus) ameliorates atherogenic lipid in hypercholesterolaemic rats. Clin Exp Pharmacol Physiol 2003; 30(7): 470-5.

[20] Alam N, Amin R, Khan A, et al. Comparative effects of oyster mushrooms on lipid profile, liver and kidney function in hypercholesterolemic rats. Mycobiology 2009; 37(1): 37-42.

[21] Seline KG, Johein H. The determination of L-carnitine in several food samples. Food Chem 2007; 105: 793-804.

[22] American Institute of Nutrition (AIN), Purified diet for laboratory rodent. Final Report. ADHOC Writing Diet. J Nutr 1993; 123: 1939-51.

[23] Schermer S. The Blood Morphology of Laboratry Animals. Philadelphia: F. A. Davies Co. 1967; p. 359.

[24] Black K. In: Business Statistics for Contemporary Decision Making. $4^{\text {th }}$, Wiley-India 2004.

[25] Fossati P, Prencipe I. Serum triglyceride determination colorimetrically with an enzyme that produce hydrogen peroxide. Clin Chem 1982; 28: 2077-83.

[26] Friedwald WT, Levy RT, Fredrickson DS. Estimation of the concentration of low density lipoprotein cholesterol in plasma without use of the preparative ultracentrifuge. Clin Chem 1972; 8: 499-505.

[27] Demacker PM, Von-Janssen HE, Hifman AM, et al. Measurement of high density lipoprotein cholesterol in serum. Comparison of sex isolation methods combined with enzymatic cholesterol analysis. Clin Chem 1980; 26: 1780-9.

[28] Richmound W. Preparation and properties of cholesterol oxidase from Nacardia sp. and its application to enzymatic assay of total cholesterol in serum. Clin Chem 1973; 19: 1350.

[29] Frings CS, Dunn RT. Colorimetric method for determination total serum lipids based on the sulphopospho vanillin reaction. Am J Clin Pathol 1979; 53: 89-91.

[30] Bergmeyer HU, Harder M. A colorimetric method of the determination of serum glutamic oxaloacetic and glutamic pyruvic transaminase. Clin Biochem 1986; 24: 481.

[31] Kachmar JF, Moss DW. Enzymes, In: Tiez N, Ed. Fundamentals of Clinical Chemistry Philadelphia PA. W.B. Saunders Co 1976; pp. 666-672.

[32] Varley H, Gewenlock A, Bell M. Practical clinical biochemistry, London; Williams Heinemen Medical books, Ltd. 1980; vol. 1, pp. 741-897.

[33] Hu ML. Measurement of protein thiol groups and glutathione in plasma. Methods Enzymol 1994; 233: 380-5.

[34] Jentzsch AM, Bachmann H, Furst P, Biesalski HK. Improved analysis of malonaldehyde in human body fluids. Free Radic Biol Med 1996; 20: 251-60.
[35] Akoma O, Onuoha SA, Ajiboye MO, Akoma AO, Alawoki AM. The nutritional and sensory quality characteristics of kunun-zaki produced with the addition of hydrolytic enzymes from malted rice (Oryza sativa). J Food Technol Afr 2002; 7: 24-6.

[36] Akoma O, Jiya EA, Akumka DD, Mshelia E. Influence of malting on the nutritional characteristics of kanun-zaki. Afr J Biotechnol 2006; 5: 996-1000.

[37] Duncan DB. Multiple range and F-test. Biometrics 1955; 1: 1-10.

[38] Bobek P, Ozdín L, Kuniak L. Mechanism of hypocholesterolemic effect of oyster mushroom (Pleurotus ostreatus) in rats: reduction of cholesterol absorption and increase of plasma cholesterol removal. Z Ernährungswiss 1994; 33: 44-50.

[39] Panchamoorthy R, Carani V. Fructose-induced hepatic gluconeogenesis: Effect of L-carnitine. Life Sci 2007; 80: 1176-83.

[40] Eskandari HG, Burak Cimen MY, Tamer L, et al. Short term effects of 1-carnitine on serum lipids in STZ-induced diabetic rats Diabetes Res Clin Pract 2004; 66: 129-32.

[41] Tanaka Y, Sasaki R, Fukui F, Waki H, Kawabata T, Okazaki M. Acetyl-1-carnitine supplementation restores decreased tissue carnitine levels and impaired lipid metabolism in aged rats. J Lipid Res 2004; 45: 729-35.

[42] Sidoriak NG, Volgin DV. Effect of L-carnitine on lipid peroxidation and lipid composition in blood serum in hemic hypoxia. Ukr Biokhim Zh 1996; 68(5): 54-8.

[43] Lofgren I, Zern T, Herron K, et al. Weight loss associated with reduced intake of carbohydrate reduces the atherogenicity of LDL in premenopausal women. Metabolism 2005; 54(9): 1133-41.

[44] Augustyniak A, Skrzydlewska E. L-Carnitine in the lipid and protein protection against ethanol-induced oxidative stress. Alcohol 2009; 43: 217-23.

[45] Gueeri H. Influence on prolonged ethanol intake on the level and turnover of alcohol and aldehyde dehydrogenase and glutathione. Adv Exp Med Biol 1995; 23: 133-4.

[46] Jayakumar T, Ramesh E, Geraldine P. Antioxidant activity of the oyster mushroom, Pleurotus ostreatus, on CCl4-induced liver injury in rats. Food Chem Toxicol 2006; 44: 1989-96.

[47] Barnett C, Costill DL, Vukovich MD. Effect of L-carnitine supplementation on muscle and blood carnitine content and lactate accumulation during highintensity sprint cycling. Int J Sport Nutr 1994; 4: 280-7.

[48] Villani RG, Gannon J, Self M, Rich PA. L-carnitine supplementation combined with aerobic training does not promote weight loss in moderately obese women. Int J Sport Nutr Exerc Metab 2000; 10: 199-206.

(C) Mishra and Singh; Licensee Bentham Open.

This is an open access article licensed under the terms of the Creative Commons Attribution Non-Commercial License (http://creativecommons.org/licenses/by-nc/3.0/) which permits unrestricted, non-commercial use, distribution and reproduction in any medium, provided the work is properly cited. 